\title{
THE DEVELOPMENT OF LEARNING MODULE TRIGONOMETRY EQUATION MATERIAL INTEGRATED ISLAMIC VALUES TO IMPROVE STUDENTS LEARNING OUTCOMES
}

\author{
Evi Dian Risalatul Ummah', Nur Lailatus Solichah², Moh. Arif Purnomo ${ }^{3}$, \\ *Siti Lailiyah ${ }^{4}$, Novi Kurniawati ${ }^{5}$ \\ 1,2,3,4 Mathematics Education, Faculty of Teacher and Training, UIN Sunan Ampel \\ Surabaya \\ ${ }^{5}$ MA Hasyim Asy'ari, Sukodono, Sidoarjo \\ 1evidianrisalatul32@gmail.com \\ ${ }^{4}$ lailiyah@uinsby.ac.id (CA)
}

\begin{abstract}
Abstrak
Penelitian ini bertujuan untuk menghasilkan modul matematika yang terintegrasi dengan nilai-nilai Islam dengan penilaian otentik untuk siswa kelas sebelas MA Hasyim Asy'ari Bangsri, Sukodono, Sidoarjo, yang layak dan unggul untuk meningkatkan prestasi siswa dalam matematika. Penelitian ini menerapkan Model pengembangan Plomp. Metode pengumpulan data dalam penelitian ini adalah dengan menggunakan kuesioner dan tes. Data dianalisis secara kuantitatif dan divalidasi. Hasil penelitian ini adalah: 1) Modul Matematika Nilai Islam dilampirkan dengan penilaian otentik dalam proses belajar mengajar. 2) Hasil penilaian ahli terhadap bahan ajar menunjukkan bahwa pengembangan modul matematika nilai-nilai islami dengan penilaian otentik memenuhi syarat baik. 3) Validator media memberikan respons yang baik. 4) Persentase keseluruhan tanggapan siswa pada tes kelompok kecil adalah $88 \%$ yang dapat dianggap memiliki kualifikasi yang baik. 5) Tanggapan guru pada tes lapangan menunjukkan bahwa guru merespons dengan baik. 6) Pengembangan modul matematika realistis ini efektif untuk meningkatkan hasil belajar siswa kelas sebelas di MA Hasyim Asy'ari Bangsri, Sukodono, Sidoarjo.
\end{abstract}

Kata kunci: pengembangan, model Plomp, modul matematika, penilaian otentik, prestasi belajar matematika

\footnotetext{
Abstract

This research is aimed at producing an Islamic values mathematical module with authentic assessment for the eleventh-grade students of MA Hasyim Asy'ari Bangsri, Sukodono, Sidoarjo, which is feasible and superior to improve students' achievement in mathematics. This research implemented Plomp's Model of development. Collecting data methods in this research is by using questionnaires and tests. The data analyzed quantitative and validation. The results of this research are: 1) Islamic Values Mathematics Module attached with authentic assessment in the teaching and learning process. 2) The result of the expert judgment on teaching material shows that the development of Islamic values mathematical module with authentic assessment
} 
is qualified as good. 3) The expert on media gives good respond. 4) The overall percentage of the students' response to a small group test is $88 \%$ that can be considered as having good qualifications. 5) The teacher's response to the field test shows that teachers responded well. 6) The development of this realistic mathematics module is effective to improve the learning result of the eleventh-grade students in MA Hasyim Asy'ari Bangsri, Sukodono, Sidoarjo.

Keywords: development, Plomp model, mathematics module, authentic assessment, mathematics learning achievement

Citation: Ummah, E. D. R., Solichah, N. L., Purnomo, M. A., Lailiyah, S., Kurniawati, N.. 2019. The Development Of Learning Module Trigonometry Equation Material Integrated Islamic Values To Improve Students learning Outcome. Matematika dan Pembelajaran, 7(2), 70-80. DOI: http://dx.doi.org/10.33477/mp.v6i2

\section{INTRODUCTION}

Education is important for the establishment of a country. The civilization of a country is said to be advanced one of the factors seen is the education system implemented in the country. Education functions to develop capabilities and shape the character and civilization of a dignified nation in the context of intellectual life of the nation aims to develop the potential of students to become human beings who believe and fear God Almighty, noble, healthy, knowledgeable, capable, independent creative, and become democratic and responsible citizens (Depdiknas, 2001).

In Indonesia, education has experienced various dynamics of change almost every year to make Indonesian education better. The curriculum change is no exception. At present, Indonesia is implementing a 2013 curriculum, replacing the previous curriculum that is Education Unit Level Curriculum/KTSP 2006. In this new curriculum, students are required to more actively look for information, while the teacher plays a more facilitating role in learning.

This change in the learning system is not all schools can implement it smoothly. Students are very heterogeneous in their characteristics. So, for active students who easily follow the learning, it is different from passive students. Therefore, with the change in the active student learning system, teachers are required to have many innovations in the learning process, especially in mathematics. Mathematics is one of the difficult subjects for most students, students 
tend not to like this lesson. This makes learning in the classroom unpleasant and boring. Besides, modules or reference sources that are used not infrequently actually increase the boredom of students (Lailiyah and Hariyanti, 2017).

Various efforts were developed to improve the quality of learning. One way that can be done is to develop learning media in the form of teaching materials. According to Suryosubroto (2009) said that the provision of a variety of teaching media will be very useful for children to learn according to different ways of learning. Learning materials have a very important role in learning activities. According to Sungkono et al (2003), learning material is a set of material that contains learning material or content that is designed to achieve learning objectives. Teaching material is systematic meaning it is arranged in order so that it makes it easier for students to learn.

According to Majid (2009), teaching materials are all forms of materials used to help the teacher/instructor in carrying out teaching and learning activities. The material in question can be either written or unwritten material. Teaching material includes, among others: Instructions for learning (student/teacher's instructions), competencies to be achieved supporting information, exercises, work instructions, can be in the form of Worksheets, evaluations. According to Finch \& Crunkilton in Lasmiyata (2014) suggested that teaching materials are resources that can help teachers in bringing about desired behavioral changes in individual students. There are several types of teaching materials as curriculum material, that are printed teaching materials, audio-visual material, and manipulative assistive devices. Teaching material is systematic, meaning that it is arranged to facilitate students learning. One source of teaching material that can be used is the module. According to Nasution (2008), modules can be formulated as a complete and standalone unit and consist of a series of learning activities arranged to help students achieve several goals that are specific and formulated. The understanding of the module according to Suryosubroto (2009) is a kind of unit of learning activities that are planned and designed to help students complete certain goals. While according to the Department of National Education defines that the module as a unit of learning material presented in the form of self-instruction. Based on the 
understanding of the module above, it can be concluded that the module is programmed learning materials that are arranged in an integrated, systematic, and detailed manner. By studying the contents of the module, students are directed to the search for a goal through certain learning methods. Therefore, the module is referred to as a package program for learning purposes.

The results of interviews with the head of curriculum affairs Mrs. Sri Asnanik that learning devices in schools have textbooks and worksheets. Due to the lack of textbooks for the 2013 curriculum in school, not all students can borrow textbooks. Meanwhile, for the understanding of material in class XI Odd Semester namely trigonometric equations, the facts in the field many students do not understand the basics of trigonometry because they get trigonometry basic material only in class $\mathrm{X}$. While in the old curriculum the basic trigonometry has been obtained in class IX.

Other research that is relevant to this research is from Wayan, Nyoman, and Made (2018) said that the development of realistic mathematics modules with authentic assessment can improve students' learning outcomes. The difference between this research and our research is that our research uses an integrated module of Islam, there is information about Islamic figures in the field of mathematics and some exercises about integrated Islam.

\section{METHOD}

This type of research is Classroom Action Research. This research was conducted on September 20th, 2019 in class XI-IPA 1 MA Hasyim Asy'ari Bangsri Sukodono Sidoarjo. According to Arikunto, the research consisted of 4 stages, namely: 1) The research planning stage, 2) Activity phase, 3) Observation stage and 4) Reflection stage.

The quality of implementation is obtained from the observations of learning analyzed with the following criteria: 
Table 1. Description of Likert Scale Scores

\begin{tabular}{ll}
\hline Score & Description \\
\hline 1 & Very less \\
2 & Less \\
3 & Good \\
4 & Very good
\end{tabular}

Furthermore, the analysis of the learning outcomes test shows the value of students who have used the trigonometry equation learning module integrated Islamic values. Based on the policy at MA Hasyim Asy'ari Bangsri Sukodono Sidoarjo, for a minimum completeness criteria (KKM) of 80 with a classical $80 \%$. The data is analyzed by:

$$
\text { Score }=\frac{B}{N} \times 100
$$

Description:

$\mathrm{B}=$ The number of items answered correctly

$\mathrm{N}=$ The number of items.

The mastery of classroom learning is obtained using the formula:

The mastery of classroom learning $=\frac{\sum \text { Students complete }}{\sum \text { Students }} \times 100 \%$

Meanwhile, to analyze student responses, we use the results of a questionnaire with a percentage of the number of students who have chosen each choice, using the following formula:

Index formula $\%=\frac{\text { total score }}{\text { Highest Likert score } \times \text { number of respondents }} \times 100 \%$

Values are presented as a percentage, then converted to the following criteria:

Table 2. Interpretation of Percentage of Student Responses

\begin{tabular}{cc}
\hline Percentage & Description \\
\hline $0 \%-24,99 \%$ & Very less \\
$25 \%-49,99 \%$ & Less \\
$50 \%-74,99 \%$ & Good \\
$75 \%-100 \%$ & Very good \\
\hline
\end{tabular}


Based on these criteria, student responses are said to be positive if the percentage $\geq$ $50 \%$.

\section{RESULT AND DISCUSSION}

This development research uses the Plomp model which includes several stages, including (1) Preliminary research, including preliminary observations, observations, reference searches, and opinion polls on modules that are being used in schools according to some Mathematics teachers, students concerned, and the researchers themselves observations; (2) Prototyping stage, including the design and manufacture of modules, the revision stage to the experts and preparation to the student testing phase; and (3) Assessment phase, including module trials to students.

In the preliminary research stage, researchers obtain some points that are less appropriate with the modules used in school, including no basic material or basic formulas that can be used to be able to learn the trigonometric equation material, so students find it difficult to learn and solve trigonometric equation problems. Besides, students are less interested in the appearance and content of books. This resulted in the modules being used did not give the impression that students were less enthusiastic in learning. One of the mathematics teachers we interviewed agreed with the results of the researchers' initial observations and student interviews.

Furthermore, in the design phase of prototype learning modules, researchers try to integrate Islamic material with geometry material. Besides, there are additional basic trigonometry materials at the beginning to help students learn trigonometric equation material.

Then the researcher validated one of the lecturers at UIN Sunan Ampel Surabaya and one of the mathematics teachers at MA Hasyim Asy'ari Bangsri Sukodono Sidoarjo. The validation data that the researchers obtained were qualitative in the form of input suggestions and criticisms regarding the appearance and contents of the module. The data is used for the revision stage. After the 
researcher made a revision and was judged good, the researcher tested the product to Class XI IPA 2 MA Hasyim Asy’ari Bangsri Sukodono Sidoarjo.

In the trial phase of this product, researchers conduct a pre-test first. Students are asked to work on as many as three items for 30 minutes and are allowed to open module books that they get from school. After that, researchers distributed learning modules to be studied first for 15 minutes. Next, the researcher asked students to work on the 3-point post-test questions for 30 minutes by being allowed to open books that had been distributed. At the end of the activity, the remaining 15 minutes was used to fill in the questionnaire regarding the module by students.

Table 3. The Result of Learning Test

\begin{tabular}{cccc} 
Number & $\begin{array}{c}\text { Initial } \\
\text { Name }\end{array}$ & $\begin{array}{c}\text { Pre-test Score } \\
\text { Post-test } \\
\text { Score }\end{array}$ \\
\hline 1. & ACW. & 40 & 50 \\
2. & AHF & 80 & 100 \\
3. & DS & 40 & 81 \\
4. & FA & 82 & 100 \\
5. & IS & 80 & 82 \\
6. & MRA & 35 & 80 \\
7. & MFA & 35 & 83 \\
8. & MDAN & 35 & 100 \\
9. & MMAI & 35 & 80 \\
10. & MNH & 80 & 100 \\
11. & NNA & 45 & 100 \\
12. & NA & 82 & 100 \\
13. & NWY & 80 & 83 \\
14. & RKS & 35 & 50 \\
15. & SNA & 81 & 100 \\
16. & TRG & 45 & 84 \\
17. & TNR & 82 & 100 \\
18. & YA & 45 & 80 \\
\hline
\end{tabular}

The mastery of classroom learning in pre test $=\frac{\sum \text { Students complete }}{\sum \text { Students }} \times 100 \%$

$$
\begin{aligned}
& =\frac{8}{18} \times 100 \% \\
& =44,44 \%
\end{aligned}
$$

The mastery of classroom learning in post test $=\frac{\sum \text { Students complete }}{\sum \text { Students }} \times 100 \%$ 


$$
\begin{aligned}
& =\frac{16}{18} \times 100 \% \\
& =88,88 \%
\end{aligned}
$$

In addition to the above data, researchers also added data on the mastery of learning obtained by researchers through pre-test and post-test, an increase in exhaustiveness learning in class XI IPA 2. The average value obtained by students after the pre-test was 36.05. This differs greatly from the average post-test results after using the learning module that is 80.67 . There was an average difference between pre-test and post-test of 44.62 points.

From the data obtained there is a difference between learning outcomes before and after the provision of this teaching material. Improved learning outcomes like this make researchers confident of concluding that using the mathematics module of trigonometric equation XI material can improve student learning outcomes.

\begin{tabular}{|c|c|c|}
\hline No. & Comments & Percentage \\
\hline 1. & Use language that is easy to understand & $99 \%$ \\
\hline 2. & Use of images by image content & $74 \%$ \\
\hline 3. & The colors and pictures chosen are attractive & $67 \%$ \\
\hline 4. & Type and size of letters used are & $93 \%$ \\
\hline 5. & Clarity of contents & $93 \%$ \\
\hline 6. & $\begin{array}{l}\text { The suitability of writing the table of contents with } \\
\text { the contents of the learning module }\end{array}$ & $93 \%$ \\
\hline 7. & Learning indicators are easy to understand & $89 \%$ \\
\hline 8. & $\begin{array}{l}\text { Clarity of learning indicators as guidelines for } \\
\text { material developed }\end{array}$ & $86 \%$ \\
\hline 9. & Ease of understanding the concept map & $85 \%$ \\
\hline 10. & $\begin{array}{l}\text { Conformity of concept maps with learning } \\
\text { material }\end{array}$ & $90 \%$ \\
\hline 11. & Interest in a brief of biography & $93 \%$ \\
\hline 12. & Language is easy to understand & $90 \%$ \\
\hline 13. & $\begin{array}{l}\text { Accuracy in the placement of layout elements } \\
\text { (topics, subtopics, and illustrations) }\end{array}$ & $90 \%$ \\
\hline 14. & $\begin{array}{l}\text { Clarity of vertical and horizontal spacing so that } \\
\text { one part and another appears to be separate }\end{array}$ & $90 \%$ \\
\hline 15. & $\begin{array}{l}\text { Conformity of all illustrations in the form of } \\
\text { images displayed in the learning module }\end{array}$ & $89 \%$ \\
\hline 16. & Concept accuracy & $92 \%$ \\
\hline 17. & $\begin{array}{l}\text { Suitability of symbol and unit notation contained } \\
\text { in the material with an international system } \\
\text { reference }\end{array}$ & $86 \%$ \\
\hline
\end{tabular}

Tabel 4. The Results of Student Response Questionnaire 


\begin{tabular}{clc}
\hline No. & \multicolumn{1}{c}{ Comments } & Percentage \\
\hline 18. & $\begin{array}{l}\text { The material presented is closely related to daily } \\
\text { life }\end{array}$ & $87,5 \%$ \\
19. & $\begin{array}{l}\text { Interest in the matter of Islamic integration } \\
\text { trigonometry equations }\end{array}$ & $93 \%$ \\
20. $\begin{array}{l}\text { Conceptual wrangling (presentation of material } \\
\text { from simple concepts to more complex ones) }\end{array}$ & $93 \%$ \\
21. Student-centered (interactive presentation of \\
$\begin{array}{l}\text { material that motivates students to learn } \\
\text { independently) }\end{array}$
\end{tabular}

Based on the percentage of the results of the student response questionnaire above, positive student responses to the learning module of integrated trigonometric equation material in Islamic values.

1. In addition to what has been explained above, this development result module also has several advantages and disadvantages, including: The trigonometric equation learning module for class XI can improve student learning outcomes.

2. The learning module of trigonometry equation XI material makes students more interested in following the process of teaching and learning activities because it is equipped with Islamic material and a brief biography of the shop of Islamic mathematicians

3. This module is equipped with illustrations, practice exercises, and contextual material that integrates with Islamic material.

\section{CONCLUSION}

Based on the results of research and data analysis conducted, it can be concluded that student learning outcomes before using the learning module integrated trigonometric equation material Islamic values of $44.44 \%$ which indicates that students have not reached the specified classical completeness of $80 \%$. After students use the module learning integrated trigonometric equation 
material Islamic values of student learning outcomes of $88.88 \%$ which shows that students have reached the classically determined completeness of $80 \%$. Whereas students' responses to the learning module of integrated trigonometric equation material in Islamic values get a response greater than $50 \%$, so it can be said that learning using the integrated learning module of trigonometric equation material in Islamic values gets a positive response from students.

\section{REFERENCES}

Depdiknas. (2001). Undang-undang Nomor 20 tahun 2003 tentang Sistem Pendidikan Nasional. Jakarta: Depdiknas. (Citation from book)

Finch, R. C, \& Crunkilton R. J. (2006). Curriculum development in vocational and technical education. Virginia, VA: Polytechnic Institute and State University. (Citation from book)

Lailiyah, Siti and Hariyanti, Ayuk (2017) Pengembangan perangkat pembelajaran berbasis masalah Matematika dengan strategi Draw a Picture. In: Prosiding Seminar Nasional Matematika dan Pendidikan Matematika Tahun 2017, 6 Desember 2017, Bandung - Indonesia. (Citation from proceeding)

Lasmiyata, Idris Harta. (2014). Pengembangan Modul Pembelajaran untuk Meningkatkan pemahaman Konsep dan Minat SMP, Jurnal Pendidikan Matematika, Volume 9 (hlm.163. Surakarta: Universitas Muhammadiyah Surakarta.

Majid, Abdul. (2009). Perencanaan Pembelajaran: Mengembangkan Standar Kompetensi Guru, (Bandung: Alfabeta, 2009), hal.173. (Citation from book)

Nasution, S. (2008). Berbagai Pendekatan dalam Proses Belajar dan Mengajar. Jakata: Bumiaksara. (Citation from book)

Nidlomuddin, A N. (2012). Penerapan Pendekatan Brain Based Learning untuk Meningkatkan Hasil Belajar Siswa pada Materi Hidrolisis Garam Kelas XI SMAN 1 Cerme Gresik. Disertasi tidak dipublikasikan. Surabaya: Universitas Negeri Surabaya. (Citation from book)

Sungkono, dkk. (2003). Pengembangan Bahan Ajar. Yogyakarta: FIP UNY. (Citation from book)

Suryobroto, B. (2009). Proses belajar mengajar di sekolah. Wawasan baru, beberapa komponen layanan khusus. Jakarta: Rineka Cipta. (Citation from book)

Wayan, S., Nyoman N., Made C. (2018). Pengembangan Modul Matematika Realistik Disertai Asesmen Otentik untuk Meningkatkan Hasil Belajar Matematika Peserta 
Ummah, E. D. R., Solichah, N. L., Purnomo, M. A., Lailiyah, S., Kurniawati, N. 2019. The Development Of Learning Module Trigonometry... Matematika dan Pembelajaran, 7(1), 80 of 80

Didik Kelas X di SMK Negeri 3 Singaraja. Jurnal Ilmiah Pendidikan dan Pembelajaran. (Citation from Journal) 